\title{
THE IDEAL OF WOMANHOOD AS A FACTOR IN MISSIONARY WORK
}

\section{INDIAN WOMEN IN THE PAST AND TO-DAY}

The most insistently pressing question concerning India is its social problem, the root of which lies in the condition of its women.

It is not within the scope of a paper such as this, nor is it possible for the writer with her limited experience of one or two provinces of her country, to enter into a detailed account of the various conditions in different parts of India which modify or alter the character of woman at the present time. It is the history of the past which has moulded Indian women on certain definite lines and given them a heritage that we may well study, in order to understand what the women of India have retained or lost in their journey across thirty centuries of years. Only after such a retrospect can we predict with any certainty what the relation of women will be to the new India.

In the ancient odes and hymns preserved for over three thousand years, we have a fair picture of woman in the early Aryan days. Natural phenomena were known as gods whose help was sought by prayer and sacrifice, offered by the head of the family, assisted, it would seem, by his wife. Woman was held in honour. There were even women rishis (seers) whose hymns are still in existence. No other nation at so early a period seems to have held its women in greater reverence.

Ancestor-worship, which soon developed into the patriarchal type of family life, initiated that inequality of the sexes which ended in the complete social disabilities 
of women. Because the father was the high priest, sons were desired to carry on the rites essential to the well-being of ancestors, and women came to be of less value. In the joint-family system, where three or four generations lived together in one house under the control of the head, the women suffered in character, becoming more and more dependent. But they were not secluded in any way, nor were they wholly without education. They exercised a wholesome influence in society, and some were noted for their learning in science and theology.

In the early days there seems to have been no religious obligation that every girl must be married. Nor was infant marriage the rule, for there are rules laid down for the selection of husbands which could not have been intended for the guidance of infaris : 'Many a woman is attracted by the wealth of them who seek her, but the woman of gentle nature and graceful form selects, among many, her own loved one as her husband.' Women such as these have been praised in song, in the Mahabharat and elsewhere :

\footnotetext{
Our love these sweetly-speaking women gain, Where men are all alone, companions bright, In cluty wise to judge, and guide aright, Kind teachers, mothers in distress and pain. . . The wife is half the man, his priceless friend: Of pleasure, virtue, wealth, his constant source, A belp and stay along his earthly course, Through life unchanging, yea beyond its end.
}

These lines describe a more exalted feminine type than the woman 'uncertain, coy and hard to please,' who occasionally in times of need assumes the form of a ministering angel. The joint-family system soon led to family discord; the power of the mother-in-law increased; the young bride learned to dread her future home. Larger and larger marriage portions became the custom; it was little wonder that girls were unwelcome, and infanticide common. 
The rise of the Brahminic system, with its elaborate ritual, and, later, the idolatrous practices and gross superstitions which continued to creep into Hinduism from the aboriginal religions it absorbed into itself, brought woman still lower, but the poor victims heeded nothing so long as the wrongs done to them came in the name of religion. Child-marriage and idol-worship and the caste system were distinctly interrelated. Child-marriage, indeed, was almost a necessity, for individual selection would have often meant marriage outside the caste limit; thus it was made incumbent upon parents as a religious duty to marry their children at an early age.

At first only widows with children were forbidden to re-marry; Manu's Law-book ordained that none might marry. Sati, another cruel law enforced on women by the Brahmins, was devised apparently for the protection of men lest young widows should poison their old husbands in order to inherit and enjoy their wealth. It was interpreted not only as an expression of wifely devotion to her lord and master, without whom life was nothing worth, but as a sacrificial act, whereby the widow could obtain release and salvation: 'As many hairs in the human body, multiplied by a crore and a half crore, so many years will she live who dies with her husband.' The older injunction to a widow was completely ignored: 'Rise up, woman, thou art lying by one whose life is gone, come to the world of the living and become the wife of one who is willing to marry thee.'

Yet, with all the wrongs imposed upon her, the Hindu woman has risen above her circumstances in an extraordinary way. Her religiousness has kept her from bitterness and discontent; she is self-denial personified; her life is one of self-effacement in the service of her husband and children. Her lifelong lesson has been well learned, 'We come after the men, and live only for their pleasure.' Religion is her life. Full of devotion, she observes fasts and feasts to obtain the favour of the gods for her husband 17 
and children-every stray fagir gains by her picty and charity; and by her meekness she does inherit the earth, for her husband pays her honour and is guided by her in all matters relating to home life.

In spite of their professed inferiority, women have for generations been the real rulers of the home. The greatest blow to womanhood was when through the Mohammedan invasion Islam invaded the sacred precinct of the home, where the Hindu woman had reigned supreme, and the sanctity of the marriage tie was a lifelong sacrament for the woman who could not be divorced. Though polygamy was not prohibited, it was permissible only where there was no son to perform those funeral rites necessary for the salvation of the parent; Mohammedanism brought in the zenana system, and by the seclusion of woman deprived public life of her refining society, setting up a false standard of purity and modesty and an environment full of suspicion and intrigue. Polygamy and easy divorce degraded the position of woman more surely than the cruelties of sati.

It seems difficult to understand why a monotheistic religion should degrade its followers below a religion full of idolatry and superstition, until one learns from personal experience that to the Hindu woman the one Supreme Being is a reality at the back of all, whilst to the Moslem, to a great extent, the Man-Prophet is an overwhelming personality-the man perhaps, more than the prophet. Further, the Moslem woman, even in the name of religion, is denied public worship, and her life is narrowed down to the four walls of the zenana; whilst the Hindu has her places of worship, many of them amongst the most beautiful spots to be found on God's earth. Her pilgrimages, high days and holy days form a large part of her life and relieve it of monotony, bringing to her seasons of lofty spiritual enjoyment. Religious zeal and personal devotion to the Prophet, as shown in fasting and praycr, are the characteristics of the Mohammedan woman's religion ; pict y, devotion, 
charity and tolerance to all men form the everyday religion of the Hindu. Why women whose own intrinsic worth has given them absolute power in the home life should be hemmed in by an elaborate system of limitations imposed by man is not easy to understand, unless it be that man has always at heart been afraid of their power, little knowing that by narrowing their sphere their influence has gained in inteisity ; to-day, the majority of married women in India, from the high zenana to the poor outcast, hold their own as much as women anywhere.

The Indian woman has often been described as inane, frivolous, a toy to be taken up and put away at pleasure. But such is not her real character. Narrow and trivial she is because of her circumstances, but all who know her intimately are struck by her strength. She is strong to love, strong to suffer, and strong to serve. Even her faults are the faults of this very strength of character, for she is equally strong to hate; she can reign as a tyrant, and is a past master in cruelty when she is thwarted, and from her inferiors she extorts a slavish obedience and service.

These are some of the chief traits connecting each generation with the past and the future, which make the Indian woman an unsolved enigma; giving to the world such high types of womanhood as command the admiration of all, and at the same time proverbs and idioms classing woman as lower than the animals : 'We all believe in the sanctity of a cow and the depravity of woman.' To Buddha it was promised, for his piety, that he should never in the process of transmigration be born in hcll, or as vermin, or as a woman.

So far, we have sketched briefly the Indian woman's journey of life from the early Aryan days to the Mohammedan invasion. It is impossible to measure accurately how far the masses have been affected by the British invasion, we stand too near to catch the right perspective of the picture; but there are signs that no such radical 
changes have ever before been effected with regard to the condition of women as those which have come from India's contact with a Christian environment.

A Christian government can never be neutral except in the letter. Its laws are based on the great principle of the fatherhood of God and the brotherhood of man. Its very tolerance to other religions preaches the spirit of Christ. The value of life and the equality of the sexes was recognized in 1829, when Lord William Bentinck's government prohibited sati in the face of much opposition from orthodox Hindus. Times have changed since then; one never meets a man to-day who would dare to raise a voice to bring back that cruel rite; it is only some poor widow, doomed to a lifelong sati, who expresses the wish that an easier and shorter way out of life was still open to her. Next came the legalizing of re-marriage for Hindu widows in 1865, and a persistent fight by the British Government against female infanticide, reforms which the Mohammedans had attempted to effect, but in vain. Not that these laws have brought in any great changes as yet, but the standard to which each generation is gradually rising has been set. It is the women themselves who are hindering the day of their deliverance; the educated men of India, who have learned that 'No nation has ever risen beyond the level of its women,' are more ready to give than the women to receive.

The rapid education of men has changed their fundamental beliefs in Hinduism; idolatry is given up ; caste is of small account, for with the new national spirit is growing a demand for equality; the main thing needed to put these ideas into practice is the like-mindedness of the women, the real home-rulers who are at least half a century behind the men. At present only a small percentage of women are able to read and write-not more than one per cent; but the influence of every enlightened woman has been disproportionately powerful. The famous words of Lord Dalhousie in a Despatch on the 
subject of female education are verified by everyday experience : "This means a far greater proportional impulse to the educational and moral tone of the people than the education of males.'

Reading and writing have not been the main factors in producing a progressive attitude amongst women ; more has been done by their coming in contact with the Christian women of the West. As teachers, physicians and foster-mothers to the orphan they have preached God's eternal laws in relation to sex-teaching that the religion of Jesus Christ demands the same moral code for man and woman. Familiarity with zenana hospital methods, facilities of travel, exhibitions, purdah parties and literature containing the history of modern western movements are all moulding the Indian woman, and making her face her relation to the new order of things. So far, what knowledge she possesses of the western woman has come to her through distinctly Christian channels, women who have given up family ties and home to minister to their less fortunate sisters. But the one who appeals to her most is the Indian Christian sister; the others fill her mind with admiration, but they are too high for her to reach; with her fellow-countrywomen she feels that it is only the religion of Jesus which has made the difference, not nationality or climate. It is the day of opportunity for the Christian women of India; they are not only messengers, but living witnesses to the regenerating power of Christ.

As yet the Indian Christian woman seems scarcely to have realized the greatness of the privilege and responsibility laid apon her by God. Nor perhaps has the missionary educationalist who has the training of her.

There is something pathetic in the devotion and romantic attachment of the women of other religions to the Christian, who stands to them as their ideal in everything, from their simple attire to their home or professional life. In schools we find the children cling to the Christian teachers more 17 . 
than to their co-religionists, and even to their Christian classmates, who are often their social inferiors. It is impossible to overrate the important part which the present-day Christian educationalist plays in the enlightenment and advance of India's women. It depends very much on her ideals and practice what the coming Christian woman will be to her countrywomen, for in God's providence there are signs that she may be as the leaven whereby to leaven the heart and soul of India, its womanhood. Most of these women, who are to be found in positions of trust and influence, or are leaders in literature, reform and philanthropy, are either Christian by religion or they have been leavened by distinctly Christian teaching and influence.

Two privileges of Christian women are specially envied : first the right of choice, not so much the choice of a husband as the right of leading an independent life, in order to minister to the needs of a larger world than that of home. How often one and another says to us : 'You must have led holy lives in a previous existence to be born into such happiness in this life as to be able to help many'; or the reverse: 'We must have greatly sinned in the last life as we have to eke out our lives so miserably in this.' 'Can there be any hell greater than this, where we are kept out from light and knowledge? This is hell-to be born a woman like me.' And the position of the Christian woman as sole wife is envied, for at heart every woman hates polygamy. 'Christianity is the only religion for women,' said a leading Sikh gentleman to me, and he added that Christian women were far ahead of their men in moral worth. ${ }^{1}$

Woman has brought from the past, in spite of her ignorance and disabilities, a high order of morality; her social retrogression has not meant a proportionate moral de-

\footnotetext{
1A Mohammedan lady, the editor of a woman's paper, said to a Christian friend, ' If I had the choice of a religion, I would first choose Christianity, secondly Hinduisin, and last of all Mohammedarism, for it is no religion for women.'
} 
gradation, for her backbone has been religion at all times.

The western woman philanthropist or missionary gives of her best without measure, but few understand the traits which the eastern girl has inherited, or the lives of those famous historical women who have served as models to each succeeding generation. To love, to suffer and to serve are noble qualities, but they have sometimes been used, for want of training, in wrong ways. It is for the Christian woman, more especially if she be Indian, by her own example to teach how to love wisely; to show that the glory of motherhood consists in bringing up children who will rise up and call her blessed; that to suffer rightly does not mean suffering those wrongs which are imposed contrary to God's laws ; and above all, that true service means more than self-effacement, and has for its end the highest good of those to whom it is rendered. That the lesson is gradually being taught by Indian Christian women, who are entering into the lives of their less enlightened sisters, we know certainly; but how it will ultimately enter into the life of the nation we cannot yet say. We do not believe that there will be a sudden revolution in the old order of things, - such a method would be contrary to the character of India's women, to whom custom has been the law of God, and convention the purity $\mathrm{He}$ has ordered - unless we can imagine a new generation of women to whom religion becomes a mere name.

So far, western civilization has come to the women of India as Christianity. But now that education is becoming general, and alas! out-growing the resources of missionary bodies, the greatest menace to the future of the country is that its women will be taught in ways which leave no place for religion, and their last state may become worse than the first.

The future of India depends largely on what attitude women take towards religion when modern education, like new wine, bursts the old bottles of superstitions and 
falsehood. Already the old faiths are trying to put their house into order in the face of Christian civilization, especially in the matter of their treatment of women. Hindu men are constantly advertising for educated wives, inserting a clause that 'caste does not matter,' or 'a nationalist preferred,' and are striving to bring in new marriage laws. A leading Moslem writes : 'It is earnestly hoped that before long a general synod of modern doctors will authoritatively declare that polygamy, like slavery, is abhorrent to the laws of Islam.' But whatever reforms men may desire to effect in the name of civilization or philanthropy, the women of India will not be moved; the only explosive force to them has been and will be religion.

If harm has been done in the past by disassociating religion from education with regard to the men of India, yet the worst has not come; much may still be saved by taking warning in time and seeing that the women are taught the wisdom that is from above, the only foundation for the highest civilization. It is not only the eastern woman who will gain by such teaching; who can tell but that from her self-effacing ministry in the family life the women of the West may learn to take a more comprehensive view of service? While the women of India need to enlarge their conception of family life, the women of the West need equally to remind themselves that a larger sphere or morc power in national life, to be of real good, must have as its centre-the home.

There is much in the signs of the times to fill us with hope for the future of India. Women are awakening to a sense of their needs, especially with regard to education, and, in consequence, to their failure to be wise mothers and true helpmates to their husbands. There is also a growing desire to be of real help to their generation, and this self-consciousness is leading many of them to pray for their day of deliverance as never before. The following pathetic utterance of a Hindu girl in a mission school 
voices the cry of many a woman who has come to the 'dividing of the ways':

O Lord, hear my prayer! No one has turned an eye on the oppression that we poor women suffer. . . O Lord, enquire into our case. For ages dark ignorance has brooded over our minds and spirits. Like a cloud it rises and wraps us around. We are like prisoners . . . choked and buried in the dust of custom, and we have no strength to get out. Bruised and beaten we are like the dry husks of the sugar-cane, when the sweet juice has been extracted. All-knowing God, hear our prayer, forgive our sins, and give us power to escape, that we may see something of Thy world. . . . Criminals in gaols are happier than we, for they know something of Thy world. They were not born in prison, but we have not for one day, not even in dreams, seen Thy world. To us it is nothing but a name, and not having seen Thy world, we cannot know Thee its Maker... we only see the four walls of the house. Shall we call them the world or India? O Father of the world, hast Thou not created us? or has some other God made us? Dost Thou care only for men? Hast Thou no thought for us women? ... Create in the hearts of men some compassion that our lives may no longer be passed in vain longing, that saved by Thy mercy we may taste something of the joys of life. ${ }^{1}$

Surely the Deliverer will make no long tarrying, and when He comes, in answer to such prayer, it will be to bring

The fading flower of poor humanity

To perfect blossoming and sweetest fruit.

KHEROTh M. Bose

'Until the Shadows flee away' (C.E.Z.M.S.), p. 32. 